\title{
Adenosine Receptor Agonists
}

\author{
Markus Wallner ${ }^{1,2,3}$, Piotr Ponikowski ${ }^{4}$
}

1. Division of Cardiology Medical University of Graz, Austria

2. Temple University Lewis Katz School of Medicine, Cardiovascular Research Center, Philadelphia, PA, USA

3. CBmed GmbH - Center for Biomarker Research in Medicine, Graz, Austria

4. Head of the Department of Heart Diseases, Wroclaw Medical University and Head of the Cardiology Department at the Center for Heart Diseases at 4th Military Hospital, Wroclaw, Poland

\section{Corresponding author:}

Prof Piotr Ponikowski, Head of the Department of Heart Diseases,

Wroclaw Medical University and Head of the Cardiology Department at the Center for Heart Diseases at 4th Military Hospital, Wroclaw, Poland.

Email: piotrponikowski@4wsk.pl

\begin{abstract}
Adenosine is a purine nucleoside that binds to adenosine cell surface receptors, which are widely expressed in heart and blood vessel cells as well as in the brain, kidney and adipose tissue. There are 4 subtypes of $P 1$ (adenosine) G protein-coupled receptors (GPCR), named $A_{1}, A_{2 A}, A_{2 B}$, and $A_{3}$, which mediate a variety of cardioprotective and regenerative effects. In the heart, these effects are predominantly mediated through $\mathrm{A} 1$ receptors $(\mathrm{A} 1 \mathrm{R})$, which are expressed in atrial and ventricular cardiomyocytes and smooth muscle cells. Pre-clinical studies have reported multiple potential benefits achievable by modulation of adenyl cyclase with beneficial effects in a variety of pre-clinical models of cardiovascular disease including chronic heart failure (HF). A1R blockade (e.g. rolofylline) was however not successful in the PROTECT trial, where 2033 patients with acute HF and renal dysfunction were randomized to rolofylline or placebo, showed no benefit on renal function, symptoms, rehospitalization, or mortality. Following this attention turned to partial adenosine agonists, capadenoson and neladenoson bialanate hydrochloride, which has two phase II studies underway, PANACHE (HFpEF) and PANTHEON (HFrEF).
\end{abstract}

Keywords: heart failure; adenosine receptor agonists

Citation: $\quad$ Wallner M, Ponikowski P. Adenosine Receptor Agonists. International Cardiovascular Forum Journal. 2019;18:11-14. DOI: 10.17987/icfj.v18i0.613

\section{Introduction}

Advances in the management of acute coronary syndrome[1] and improvements in heart failure (HF) treatment have led to significant reductions in both morbidity and mortality.[2-4] Such changes are thought to be responsible for an increase in the prevalence of $\mathrm{HF}$ as patients with cardiovascular disorders are living longer and the world population is ageing. Thus, HF has become one of the most prevalent cardiovascular (CV) diseases in the Western world[5], with a mortality exceeding that of many types of cancer.

Although several early therapeutic breakthroughs (for example neurohumoral inhibition) have significantly improved mortality and morbidity in patients with HF with reduced ejection fraction (HFrEF) from the 1980's to the first decade of the millenium, relatively fewer successes have been reported during the past decade. [6] A purported reason for the failure of recent HFrEF treatment trials may be that the addition of yet more haemodynamically active (usually vasodilatory) agents to the standard treatment of care may cause adverse effects such as hypotension or bradyarrhythmias, and thus, incremental improvements may be unattainable with these agents.[7] Data from the ESC Heart Failure Long-Term Registry have demonstrated that desirable target doses for RAAS-blockers, MRAs, and B-blockers were only achieved in about $30 \%$ of patients with chronic HF.[8] These safety concerns have guided the field of research, and there is now a focus on developing novel treatment strategies directly targeting intrinsic myocardial properties, without significantly affecting haemodynamics. $[9,10]$ This shift in focus has led to the development of partial adenosine receptor agonists[11], a group of agents which are thought to be haemodynamically neutral.

\section{Adenosine Receptor Signalling}

Adenosine is a purine nucleoside that binds to adenosine cell surface receptors, which are widely expressed in heart and blood vessel cells as well as in the brain, kidney and adipose tissue.[12,13] There are 4 subtypes of $\mathrm{P} 1$ (adenosine) G proteincoupled receptors (GPCR), named $A_{1}, A_{2 A}, A_{2 B}$, and $A_{3}$, which mediate a variety of cardioprotective and regenerative effects. $[14,15]$ In the heart, these effects are predominantly mediated through $\mathrm{A} 1$ receptors $(\mathrm{A} 1 \mathrm{R})[11]$, which are expressed in atrial and ventricular cardiomyocytes[16] and smooth muscle cells. [17] Activation of $A 1 R$ reduces the intracellular levels of cyclic adenosine monophosphate (cAMP) by inhibiting adenyl cyclase[18], modulating protein kinase $C$, and opening ATPsensitive potassium channels (Figure 1).[19] 


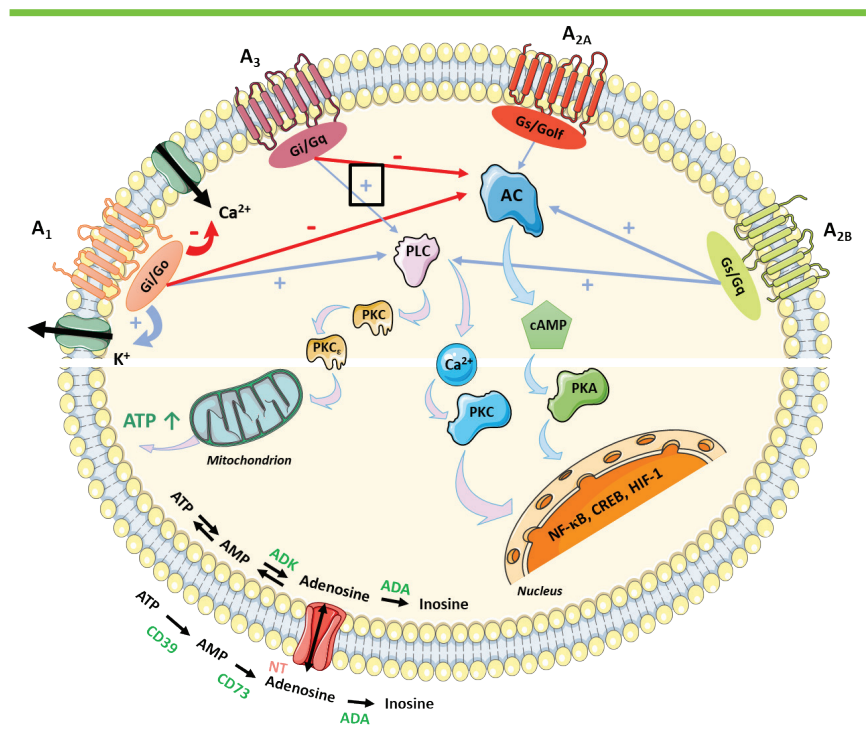

Figure 13.1. Adenosine metabolism and signaling Adenosine can be produced intracellularly via hydrolysis of AMP by 5 - nucleotidase. Extracellular synthesis of adenosine occurs via ATP dephosphorylation by ectonucleoside triphosphate diphosphohydrolase CD39 and 5B-nucleotidase CD73. Adenosine can be degraded to inosine by ADA or phosphorylated to AMP by ADK, both intracellular. Signaling pathways of adenosine receptor subtypes $\left(A_{1}, A_{2 A}, A_{2 B}, A_{3}\right)$. $A C$, adenylyl cyclase; $A D A$, adenosine deaminase; $A D K$, adenosine kinase; cAMP, cyclic AMP; CREB, cAMP response elementbinding protein; HIF-1, hypoxia-inducible factor; NF-kB, nuclear factor $\mathrm{kB}$; NT, nucleoside transporter; PKA, protein kinase $A$; PKC, protein kinase C; PLC, phospholipase C.

Pre-clinical studies have reported that modulation of adenyl cyclase attenuates sympathetic over-activation and stimulates a release of atrial natriuretic peptide.[20] Furthermore, it has been shown that an adenosine activation of $A 1 R$ improves mitochondrial function[21,22], attenuates cardiac hypertrophy and fibrosis[23], modulates derangements in cardiac metabolic profile[24], and exerts cardioprotective effects by maintaining intracellular calcium homeostasis and preventing ischaemia. Due to this broad spectrum of mechanisms, adenosine A1R activation has been shown to exert beneficial effects in a variety of pre-clinical models of cardiovascular disease associated with ischaemia/reperfusion (I/R), arrhythmogenesis, myocardial stunning, ventricular dysfunction, acute myocardial infarction, apoptosis, and chronic heart failure (Table 1).[25-27]

\section{Concept of Adenosine A1R Blockade}

Several complex effects of adenosine on the kidney, such as sodium reabsorption in the proximal tubules, vasoconstriction of afferent renal arterioles, and enhanced tubuloglomerular feedback in the macula densa have been described, which all lead to fluid overload and decreased glomerular filtration rate. $[28,29]$ Approximately $50 \%$ of chronic HF patients and $2 / 3$ of patients with acute HF have renal dysfunction, therefore adenosine-related renal effects are highly undesired and raise major safety concerns.[30] These renal effects raise the question whether adenosine A1R blockade may be potentially beneficial in $\mathrm{HF}$ and this led to large-scale drug development programs with adenosine A1R antagonists (e.g. rolofylline).
Table 1. Adenosine receptor signaling. Beneficial effects of partial A1R agonists in heart failure

Energy Metabolism
Fatty acid oxidation $\uparrow$
Glut- 1 and Glut- 4 expression $\uparrow$
LV Anti-Remodeling Effects
LV hypertrophy $\uparrow$
Interstitial fibrosis $\uparrow$
Preserves myocardial capillary density
Preserves oxygen diffusion distances
End-systolic volume $\uparrow$
Mitochondrial Function
ROS production $\uparrow$
Opening rate of mitochondrial permeability transition pores $\uparrow$
Apoptosis $\uparrow$
ATP production $\uparrow$
Efficiency of electron transport chain $\uparrow$
Mitochondrial uncoupling proteins $\uparrow$
Cardioprotective Effects
Catecholamine release $\uparrow$
SERCA2a activity $\uparrow$
Protection from calcium overload

Two smaller randomized, controlled clinical trials reported positive effects of rolofylline on renal function in patients with acute and chronic HF.[31,32] However, a subsequent larger phase 3 study did not confirm these findings. In the PROTECT trial, 2033 patients with acute HF and renal dysfunction were randomized to receive either rolofylline, an adenosine $A 1 R$ antagonist, or placebo. Treatment with rolofylline showed no benefit on renal function, symptoms, rehospitalization, or mortality during the follow-up of 60 days[33], but increased rates of seizures and stroke were reported in this group. However, no temporal relation to rolofylline infusion and no specific stroke subtype which predicted stroke in the rolofylline group was reported.[34]

\section{Full vs Partial Adenosine A1R Agonists}

The neutral results of the PROTECT trial indirectly influenced the continued development of adenosine A1R agonists. Given the fact that adenosine receptors are expressed on the vast majority of cells, it became obvious that full adenosine agonists activated not only the desired target cells, but also activated cells involved in a variety of diverse physiological processes.[35] Due to the widespread distribution and diverse function of $A 1 R$, the cardioprotective effects may have been counteracted by various unintended off-target effects, such as atrioventricular block, bradycardia, and negative inotropic and dromotropic effects. $[11,12,36]$ Therefore, partial adenosine A1R agonists have been designed to exert cardioprotective and anti-remodelling effects, while maximizing safety by limiting negative side effects. In general, partial agonists are low efficacy ligands that elicit only submaximal effects compared to full agonists.[35] Therefore, 
partial A1R agonists exert tissue and functional selectivity by acting as a semi-potent agonist or weak antagonist depending on the specific tissue receptor activity.[37] Furthermore, receptor desensitization may be less of a problem with partial A1R agonists compared to full agonists, which may be particularly beneficial for long-term treatment strategies.[38,39]

VCP28, an adenosine-like A1R agonist, was found to have cardioprotective effects in experimental models of ischaemia/ reperfusion (I/R).[27] Although promising results have been reported for these adenosine-like A1R agonists, the short halflife and low bioavailability significantly limit their use for chronic oral therapy.

Capadenoson, a non-adenosine-like partial A1R agonist that elicits improved pharmacokinetics, was reported to significantly reduce infarct size in a dose-dependent manner in a pre-clinical I/R model.[39] In a canine model of HF, oral capadenoson treatment for 12 weeks improved LV function and exerted antiremodeling effects.[21] In addition in a phase II, randomized, placebo-controlled trial, capadenoson showed improved total exercise time in male patients with stable angina.[40] Although capadenoson did not cause ECG alterations, the potency for A1R may have be too high, as central effects such as vertigo were reported.

This finding led to the development of neladenoson bialanate hydrochloride, a partial A1R agonist with improved solubility and an optimized therapeutic window compared to capadenoson. [41] Two small clinical trials evaluated the safety and tolerability of neladenoson bialanate in patients with HFrEF.[42] The $\boldsymbol{\beta}$-Blocker Interaction Study, a single-centre, single-blind, placebocontrolled study, showed that a single-dose of neladenoson bialanate is safe in patients with HFrEF treated with $\beta$-blockers. The second, the PARSIFAL pilot study was a double-blind, placebo-controlled trial that showed no atrioventricular conduction disorders or neurological side effects in HFrEF patients treated with $\beta$-blockers and a 7-day course of neladenoson bialanate. However, no significant changes in cardiac function were reported. [42]

Two larger clinical, randomized, controlled, dose-finding phase II studies assessing the efficacy and safety of neladenoson bialanate are currently ongoing. The PANACHE trial randomized 305 patients with HF with preserved ejection fraction (HFpEF) to either neladenoson or placebo treatment. The primary endpoint is the absolute change from baseline in 6-minute walking distance after 20 weeks of treatment. The PANTHEON trial has a similar design to PANACHE, but enrolled 427 patients with HFrEF. The primary endpoint is absolute change from baseline in LVEF after 20 weeks of treatment.

\section{Conclusions}

While there have been 3 decades of experimental research supporting the idea that adenosine receptor signaling is advantageous in a variety of cardiovascular pathologies, there is currently insufficient evidence supporting the clinical efficacy of AR agonists in patients with cardiovascular diseases. However, with encouraging preclinical data and strong biological rationale, adenosine signaling holds promise as a potential treatment for the ever-growing HF population. The results of PANCHE and
PANTHEON will provide new evidence for the role of partial adenosine A1R agonists in heart failure therapy.

\section{Declarations of interest}

The authors declare no conflict of interest.

\section{Acknowledgements}

The authors state that they abide by the authors' responsibilities and ethical publishing guidelines of the International Cardiovascular Forum Journal.[43]

\section{References}

1. Schmidt M, Jacobsen JB, Lash TL, Botker HE and Sorensen HT. 25 year trends in first time hospitalisation for acute myocardial infarction, subsequent short and long term mortality, and the prognostic impact of sex and comorbidity: a Danish nationwide cohort study. BMJ. 2012;344:e356.

2. Investigators S, Yusuf S, Pitt B, Davis CE, Hood WB and Cohn JN. Effect of enalapril on survival in patients with reduced left ventricular ejection fractions and congestive heart failure. The New England journal of medicine. 1991;325:293-302.

3. Group CTS. Effects of enalapril on mortality in severe congestive heart failure. Results of the Cooperative North Scandinavian Enalapril Survival Study (CONSENSUS). The New England journal of medicine. 1987;316:1429-35.

4. Pitt B, Zannad F, Remme WJ, Cody R, Castaigne A, Perez A, Palensky J and Wittes $\mathrm{J}$. The effect of spironolactone on morbidity and mortality in patients with severe heart failure. Randomized Aldactone Evaluation Study Investigators. The New England journal of medicine. 1999;341:709-17.

5. Redfield MM, Jacobsen SJ, Burnett JC, Jr., Mahoney DW, Bailey KR and Rodeheffer RJ. Burden of systolic and diastolic ventricular dysfunction in the community: appreciating the scope of the heart failure epidemic. JAMA : the journal of the American Medical Association. 2003;289:194-202.

6. Vaduganathan M, Butler J, Pitt B and Gheorghiade M. Contemporary Drug Development in Heart Failure: Call for Hemodynamically Neutral Therapies. Circulation Heart failure. 2015;8:826-31.

7. Gheorghiade M, Bohm M, Greene SJ, Fonarow GC, Lewis EF, Zannad F Solomon SD, Baschiera F, Botha J, Hua TA, Gimpelewicz CR, Jaumont X, Lesogor A and Maggioni AP. Effect of aliskiren on postdischarge mortality and heart failure readmissions among patients hospitalized for heart failure: the ASTRONAUT randomized trial. JAMA : the journal of the American Medical Association. 2013;309:1125-35.

8. Maggioni AP, Anker SD, Dahlstrom U, Filippatos G, Ponikowski P, Zannad F, Amir O, Chioncel O, Leiro MC, Drozdz J, Erglis A, Fazlibegovic E, Fonseca C, Fruhwald F, Gatzov P, Goncalvesova E, Hassanein M, Hradec J, Kavoliuniene A, Lainscak M, Logeart D, Merkely B, Metra M, Persson $H$, Seferovic P, Temizhan A, Tousoulis D and Tavazzi L. Are hospitalized or ambulatory patients with heart failure treated in accordance with European Society of Cardiology guidelines? Evidence from 12,440 patients of the ESC Heart Failure Long-Term Registry. European journal of heart failure. 2013;15:1173-84.

9. Bayeva M, Gheorghiade $\mathrm{M}$ and Ardehali $\mathrm{H}$. Mitochondria as a therapeutic target in heart failure. Journal of the American College of Cardiology. 2013;61:599-610.

10. Wilcox JE, Fonarow GC, Ardehali H, Bonow RO, Butler J, Sauer AJ, Epstein SE, Khan SS, Kim RJ, Sabbah HN, Diez J and Gheorghiade M. "Targeting the Heart" in Heart Failure: Myocardial Recovery in Heart Failure With Reduced Ejection Fraction. JACC Heart failure. 2015;3:661-9.

11. Greene SJ, Sabbah HN, Butler J, Voors AA, Albrecht-Kupper BE, Dungen HD, Dinh W and Gheorghiade M. Partial adenosine A1 receptor agonism: a potential new therapeutic strategy for heart failure. Heart failure reviews. 2016;21:95-102.

12. Fredholm BB, AP IJ, Jacobson KA, Linden $\mathrm{J}$ and Muller CE. International Union of Basic and Clinical Pharmacology. LXXXI. Nomenclature and classification of adenosine receptors--an update. Pharmacological reviews. 2011;63:1-34.

13. Dixon AK, Gubitz AK, Sirinathsinghji DJ, Richardson PJ and Freeman TC. Tissue distribution of adenosine receptor mRNAs in the rat. British journal of pharmacology. 1996;118:1461-8.

14. Burnstock G. Purinergic Signaling in the Cardiovascular System. Circulation research. 2017;120:207-228.

15. Linden J. Adenosine in tissue protection and tissue regeneration. Molecular pharmacology. 2005;67:1385-7.

16. Musser B, Morgan ME, Leid M, Murray TF, Linden J and Vestal RE. Species comparison of adenosine and beta-adrenoceptors in mammalian atrial and ventricular myocardium. Eur J Pharmacol. 1993;246:105-11.

17. Hussain $T$ and Mustafa SJ. Binding of $A 1$ adenosine receptor ligand $[3 \mathrm{H}] 8$ cyclopentyl-1,3-dipropylxanthine in coronary smooth muscle. Circulation research. 1995;77:194-8. 
18. Akbar M, Okajima F, Tomura $\mathrm{H}$, Shimegi $\mathrm{S}$ and Kondo $\mathrm{Y}$. A single species of $\mathrm{A} 1$ adenosine receptor expressed in Chinese hamster ovary cells not only inhibits CAMP accumulation but also stimulates phospholipase $\mathrm{C}$ and arachidonate release. Molecular pharmacology. 1994;45:1036-42.

19. Wang $D$ and Belardinelli $L$. Mechanism of the negative inotropic effect of adenosine in guinea pig atrial myocytes. The American journal of physiology. 1994;267:H2420-9.

20. Yuan K, Cao C, Han JH, Kim SZ and Kim SH. Adenosine-stimulated atrial natriuretic peptide release through A1 receptor subtype. Hypertension. 2005;46:1381-7.

21. Sabbah HN, Gupta RC, Kohli S, Wang M, Rastogi S, Zhang K, Zimmermann $\mathrm{K}$, Diedrichs $\mathrm{N}$ and Albrecht-Kupper BE. Chronic therapy with a partial adenosine A1-receptor agonist improves left ventricular function and remodeling in dogs with advanced heart failure. Circulation Heart failure. 2013;6:563-71.

22. Brown DA, Perry JB, Allen ME, Sabbah HN, Stauffer BL, Shaikh SR, Cleland JG, Colucci WS, Butler J, Voors AA, Anker SD, Pitt B, Pieske B, Filippatos G, Greene SJ and Gheorghiade M. Expert consensus document: Mitochondrial function as a therapeutic target in heart failure. Nature reviews Cardiology. 2017;14:238-250.

23. Puhl SL, Kazakov A, Muller A, Fries P, Wagner DR, Bohm M, Maack C and Devaux $Y$. Adenosine A1 receptor activation attenuates cardiac hypertrophy and fibrosis in response to alpha1 -adrenoceptor stimulation in vivo. British journal of pharmacology. 2016;173:88-102.

24. Staehr PM, Dhalla AK, Zack J, Wang X, Ho YL, Bingham J and Belardinelli $L$. Reduction of free fatty acids, safety, and pharmacokinetics of oral GS-9667, an A(1) adenosine receptor partial agonist. J Clin Pharmacol. 2013;53:385-92.

25. Kitakaze M, Hori M, Takashima S, Sato H, Inoue $M$ and Kamada T. Ischemic preconditioning increases adenosine release and 5'-nucleotidase activity during myocardial ischemia and reperfusion in dogs. Implications for myocardial salvage. Circulation. 1993;87:208-15

26. Shneyvays V, Mamedova LK, Leshem D, Korkus A and Shainberg A. Insights into the cardioprotective function of adenosine $A(1)$ and $A(3)$ receptors. Experimental and clinical cardiology. 2002;7:138-45.

27. Urmaliya VB, Pouton CW, Devine SM, Haynes JM, Warfe L, Scammells PJ and White PJ. A novel highly selective adenosine A1 receptor agonist VCP28 reduces ischemia injury in a cardiac cell line and ischemiareperfusion injury in isolated rat hearts at concentrations that do not affect heart rate. Journal of cardiovascular pharmacology. 2010;56:282-92.

28. Birkenfeld AL, Jordan J, Dworak M, Merkel T and Burnstock G. Myocardial metbolism in heart failure: Purinergic signalling and other metabolic concepts. Pharmacology \& therapeutics. 2018.

29. Vallon V, Muhlbauer $B$ and Osswald $H$. Adenosine and kidney function. Physiol Rev. 2006;86:901-40.

30. Ronco C, Haapio M, House AA, Anavekar N and Bellomo R. Cardiorenal syndrome. Journal of the American College of Cardiology. 2008;52:1527-39.

31. Givertz MM, Massie BM, Fields TK, Pearson LL and Dittrich HC. The effects of KW-3902, an adenosine A1-receptor antagonist,on diuresis and renal function in patients with acute decompensated heart failure and renal impairment or diuretic resistance. Journal of the American College of Cardiology. 2007;50:1551-60.

32. Greenberg B, Thomas I, Banish D, Goldman S, Havranek E, Massie BM, Zhu Y, Ticho B and Abraham WT. Effects of multiple oral doses of an A1 adenosine antagonist, BG9928, in patients with heart failure: results of a placebo-controlled, dose-escalation study. Journal of the American College of Cardiology. 2007;50:600-6.

33. Massie BM, O'Connor CM, Metra M, Ponikowski P, Teerlink JR, Cotter G, Weatherley BD, Cleland JG, Givertz MM, Voors A, DeLucca P, Mansoor GA, Salerno CM, Bloomfield DM and Dittrich HC. Rolofylline, an adenosine A1-receptor antagonist, in acute heart failure. The New England journal of medicine. 2010;363:1419-28.

34. Teerlink JR, Iragui VJ, Mohr JP, Carson PE, Hauptman PJ, Lovett DH, Miller AB, Pina IL, Thomson S, Varosy PD, Zile MR, Cleland JG, Givertz MM, Metra M, Ponikowski P, Voors AA, Davison BA, Cotter G, Wolko D, Delucca $\mathrm{P}$, Salerno CM, Mansoor GA, Dittrich H, O'Connor CM and Massie BM. The safety of an adenosine A(1)-receptor antagonist, rolofylline, in patients with acute heart failure and renal impairment: findings from PROTECT. Drug Saf. 2012;35:233-44.

35. Peleli M, Fredholm BB, Sobrevia L and Carlstrom M. Pharmacological targeting of adenosine receptor signaling. Mol Aspects Med. 2017;55:4-8.

36. Fredholm BB, AP IJ, Jacobson KA, Klotz KN and Linden J. International Union of Pharmacology. XXV. Nomenclature and classification of adenosine receptors. Pharmacological reviews. 2001;53:527-52.

37. Srinivas M, Shryock JC, Dennis DM, Baker SP and Belardinelli L. Differential A1 adenosine receptor reserve for two actions of adenosine on guinea pig atrial myocytes. Molecular pharmacology. 1997;52:683-91.

38. Longabaugh JP, Didsbury J, Spiegel A and Stiles GL. Modification of the rat adipocyte $\mathrm{A} 1$ adenosine receptor-adenylate cyclase system during chronic exposure to an $\mathrm{A} 1$ adenosine receptor agonist: alterations in the quantity of GS alpha and Gi alpha are not associated with changes in their mRNAs. Molecular pharmacology. 1989;36:681-8.
39. Albrecht-Kupper BE, Leineweber $K$ and Nell PG. Partial adenosine A1 receptor agonists for cardiovascular therapies. Purinergic signalling. 2012;8:91-9.

40. Tendera M, Gaszewska-Zurek E, Parma Z, Ponikowski P, Jankowska E, Kawecka-Jaszcz K, Czarnecka D, Krzeminska-Pakula M, Bednarkiewicz Z, Sosnowski M, Ochan Kilama M and Agrawal R. The new oral adenosine A1 receptor agonist capadenoson in male patients with stable angina. Clin Res Cardiol. 2012;101:585-91.

41. Meibom D, Albrecht-Kupper B, Diedrichs N, Hubsch W, Kast R, Kramer T, Krenz U, Lerchen HG, Mittendorf J, Nell PG, Sussmeier F, Vakalopoulos A and Zimmermann K. Neladenoson Bialanate Hydrochloride: A Prodrug of a Partial Adenosine A1 Receptor Agonist for the Chronic Treatment of Heart Diseases. ChemMedChem. 2017;12:728-737.

42. Voors AA, Dungen HD, Senni M, Nodari S, Agostoni P, Ponikowski P, Bax JJ, Butler J, Kim RJ, Dorhout B, Dinh W and Gheorghiade M. Safety and Tolerability of Neladenoson Bialanate, a Novel Oral Partial Adenosine A1 Receptor Agonist, in Patients With Chronic Heart Failure. J Clin Pharmacol. 2017;57:440-451.

43. Shewan LG, Coats AJS, Henein MY. Authors' Responsibilities and Ethical Publishing. International Cardiovascular Forum Journal 2018;13:3-4, DOI: 10.17987/icfj.v13i0.525. 